\title{
TRUST GOES THE OTHER WAY TOO: SELLERS' TRUST IN BUYERS AND ITS INFLUENCE ON SALE PROCESS EFFICIENCY
}

\author{
DOI: 10.17261/Pressacademia.2020.1195 \\ JMML- V.7-ISS.1-2020(3)-p.28-41
}

Ozan Peneklioglu, Ayse Banu Elmadag ${ }^{2}$

${ }^{1}$ Istanbul Technical University, Department of Management Engineering, Macka, Istanbul, Turkey. ozanpeneklioglu@gmail.com, ORCID: 0000-0001-6849-5220

2University of Southern Mississippi, School of Marketing, Hattiesburg, MS, United States. Banu.ElmadagBas@usm.edu, ORCID: 0000-0001-6849-5220

Date Received: December 10, 2019

Date Accepted: March 16, 2020

To cite this document

Peneklioglu, O., Elmadag, A.B., (2020). Trust goes the other way too: sellers' trust in buyers and its influence on sale process efficiency. Journal of Management, Marketing and Logistics (JMML), V.7(1), p.28-41.

Permemant link to this document: http://doi.org/10.17261/Pressacademia.2020.1195

Copyright: Published by PressAcademia and limited licenced re-use rights only.

\begin{abstract}
Purpose- This research aims to discover the effect of interpersonal factors on seller's trust to buyer and in turn to the sales process effectiveness. Sales specific factors such as time risk and purchase importance are also considered when determining the effects of interpersonal factors. Methodology- A quantitative research method involving salespeople is employed.

Findings- The findings indicate the presence of a positive relationship between interpersonal factors (similarity, expertise task orientation) and trust to buyer and sales process effectiveness. The sales specific factors (time risk and purchase importance) also have a moderation effect to the relationship between trust and sales process effectiveness.

Conclusion- Through the sellers' perspective, this study investigated the antecedents and consequences of trust in a business-to-business sale relationship. Recommendations to both sales team managers and procurement team managers to increase the sales process effectiveness under specific situations is provided based on study findings.
\end{abstract}

Keywords: Sale process efficiency, trust, similarity, buyer-seller business relationships. JEL Codes: M30, M31, M39

\section{INTRODUCTION}

Business-to-Business (B2B) buying behavior had initially been accepted as the rational behavior, which is complex, systematic and unbiased by an individual or irrational criterion (Webster and Wind, 1972; Sheth, 1973). Moreover, buyers' trust in sellers has been accepted as one of the key influencers on B2B buying decision outcomes (Doney and Cannon, 1997; Johnson and Grayson, 2005; Friend, Hamwi, and Rutherford, 2011). However, more recent research has shown that trust can be influenced by personal factors and perceptions (Yang, Kim, and McFarland, 2011; Chakrabarty, Brown, and Widing II, 2013; Bateman and Valentine, 2015; Newell et al., 2016; Kalra et al., 2017) and that buyers' trust may not be the only trust that influences the relationship (Chakrabarty et al., 2013).

A broad body of research about perceived trust, from the buyer's perspective, shows that trust positively influences performance and other related outcomes (such as satisfaction, conflict resolution, communication quality, conflict resolution, and cooperation) (Graca, Barry, and Doney, 2015). Research has repeatedly confirmed that buyers' trust in sellers has a positive impact on knowledge sharing and complementary capabilities (Rungsithong, Meyer, and Roath, 2017; Swan et al 1988) as well as on buyers' satisfaction and intention to maintain/extend the relationship (Vázquez-Casielles, Iglesias, and Varela-Neira, 2017). As recently indicated by Bolander and Richards (2018, p.169), the selling and sales management research, conducted over five decades, has 
a focus on "customer-related (in a business situation buyer-related) research questions". Thus, previous literature emphasizes the influences of buyers' perceptions of sellers in B2B sales situations. However, as in all reciprocal relationships, sellers' trust in the buyer in B2B situations, although neglected by current research, may have a bearing on the sale process, specifically its efficiency. As suggested by Plouffe $(2018$, p. 241) "despite much practical and empirical attention over five-plus decades, our understanding of the sales role remains limited. .... While the sales role has been studied for more than half a century, much of what drives performance is still unknown". Therefore, it can be argued that the sellers' trust in the buyer in the sales process may be another driver for the sale performance.

The purpose of this study is to determine the influence of sellers' trust in buyers on the efficiency of a sale process. Often, if not always, the buyer's trust has been the focus of researchers in the B2B marketing literature when examining sales performance, even when data collected was based on the seller's perceptions of buyers' trust. In this research, we adopt the sellers' perspective to discover the sellers' trust in buyers and its' influence on sales performance. Sale process efficiency is one way of measuring sales performance, which is the ability of a salesperson to win the opportunity in the right timeframe (Rodriguez and Honeycutt, 2011). When firms increase the efficiency of their sales processes (or can be named as procurement process efficiency from the buying company's perspective), they reduce order cycle times thus reduce their cost, utilize their human resources more efficiently, and also may gain a competitive advantage against their competitors due to earlier introduction of new offerings to the market place and/or having higher growth than competitors. Based on the results of a survey among 1300 companies worldwide, Dickie (2004) pointed out, the sales efficiency ranked as the second priority for the companies when increasing their sales performance.

This study adopts Similarity-Attraction Theory (Byrne, 1971) and the concept of relational demography (Tsui and O'Reilly, 1989) perspectives to better explain the effects of individual buyer-seller relationships and their outcomes in B2B sales situations. In an attempt to have a deeper understanding of the individual factors affecting sale process efficiency we used seller's perceptions of buyer similarity, expertise, and task orientation as antecedents of seller's trust in the buyer and, in turn, sale process efficiency. Moreover, purchase importance is also considered as a sale specific factor when determining the effects of intrapersonal factors on trust and sale process efficiency.

In this article first, the literature review on the concept, modalities, and effects of sellers' trust in buyers is presented and conceptual background for sale process efficiency is laid out. Utilizing the data from 235 B2B sales professionals from various industries hypotheses are tested and finally, the results are discussed as well as the theoretical/ managerial implications and limitations of the study and recommendations for further research are presented.

\section{LITERATURE REVIEW}

The concept of trust has attracted great interest from researchers for decades. Introduced as an essential success factor in business relationships (Parasuraman et al. 1985), trust is described as being "central to successful relationship marketing" (Morgan and Hunt, 1994, p. 22). In these seminal studies about trust, authors have emphasized that both buyers and sellers need to trust each other to feel secure and comfortable during the selling-buying processes. However, when the B2B literature is scrutinized the majority of studies focus on buyers' trust yet ignore sellers'.

Few dyadic articles in the literature study trust from both sellers' and buyers' perspectives. However, the performance outcome investigated in those studies is relational and not specific to a sale (i.e. Lai et al, 2009; Nyaga, Whipple and Lynch, 2010). Chakrabarty et al (2013) surveyed a random sample of B2B salespeople to examine the effects of salesperson selling behaviors on salesperson's trust in the buyer and salesperson performance. In another study by Blonska et al. (2013) suppliers of one single firm were surveyed and the influence of relational capital (including trust) on buyer and supplier benefits was examined. These limited studies conclude that further research is needed to investigate the effects of the seller's trust on performance using sale process efficiency (Chakrabarty et al., 2013). Thus, in the next section literature on trust in B2B sales relationships and factors affecting sellers' trust in buyers will be laid out.

\subsection{Trust in B-to-B Sales Relationships}

Trust in the B2B context, as defined by Anderson and Narus (1990), is one partner's confidence that the other partner will perform actions that will result in positive outcomes for the firm and will not take unexpected actions that may produce negative outcomes. In the same way, Crosby et al. (1990) mentioned that "trust in relational sales contexts can be defined as a confident belief that the salesperson can be relied upon to behave in such a manner that the long-term interest of the customer will be served" and 
Moorman et al. (1992) defined trust as "a willingness to rely on an exchange partner in whom one has confidence". Although Crosby et al. (1992) only mention trust in the salesperson, later definitions show that trust is available "when one party has confidence in an exchange partner's reliability and integrity" (Morgan and Hunt, 1994) showing that trust is a two-way street.

The concept of trust in the B2B context has developed in different ways since the mid-1980s (Parasuraman et al., 1985; Swan, 1985) and has been attracting the continuing interest of academia (Massey et al., 2019). Trust is a cornerstone in the progression of the relationship between buyer and seller (Morgan and Hunt, 1994), and a key influencer of the efficiency of relationships (Johnson and Grayson, 2005). However, in many trust centric relationship studies, trust is used as a single-sided construct: buyers' trust in sellers (Akrout and Akrout, 2011). Any sale process, nevertheless, includes a certain degree of uncertainty both for buyers and sellers, which can be reduced by building trust (Gao, Sirgy and Bird, 2005). Thus, as much as buyers' trust in sellers influences sale processes, sellers' trust may also have a bearing on the sale process efficiency.

In B2B literature, researchers have utilized interpersonal (relational) factors (i.e. Swan et al, 1988), sale specific factors such as purchase importance (i.e. Doney and Cannon, 1997; Belonax et al, 2007) and seller specific factors such as ability and expertise (i.e. Swan and Nolan, 1985) as predictors of trust when buyers' trust in salespeople are concerned. Dampérat and Jolibert (2009) showed that individual factors such as relational orientation and expertise influence the relationship between buyers and sellers in the business settings because a relational approach can generate greater trust in salespeople (Bateman and Valentine, 2015) that reduces buyers' perceptions of available alternative suppliers (Friend, Hamwi and Rutherford, 2011). When sellers are concerned, based on the relational demography perspective and Similarity Attraction Theory (Byrne, 1971), one important factor that may facilitate the trust in the buyer is the relational proximity to the buyer, which may be operationalized as the perceived similarity.

\subsection{Similarity}

Similarity-Attraction Theory (Byrne, 1971) suggests that people like others who they think are similar, rather than dissimilar, to themselves, and similarity significantly attenuates interpersonal attraction, social incorporation, and likeability (Baron and Pfeffer, 1994). As expressed by Smith (1998), similarity is the extent to which similar personal attributes or characteristics in a dyadic relation between at least two people in a social group are shared. Moreover, shared common interests and values also increase perceptions of similarity (Doney and Cannon, 1997).

B2B literature affirms the existence of the relation between trust and similarity. For example, Doney and Cannon (1997) showed that buyers increase their trust in and satisfaction with sellers, who are similar to themselves; because they believe that sellers share akin values and have similar interests. Hikkerovaa (2011) found evidence that for a buyer shared values are positively linked to trust. Lichtenthal and Tellefsen (2001) propose that buyer-seller similarity can enhance the sales efficiency as a result of the increased attraction between the buyer and the salesperson, which might be a result of the increased capability in perceiving the trust-relevant signals and symbols from more similar people (Child and Möllering, 2003). A recent study of Weck and Ivanova (2013) claims that particularly at the initial phases of a B-to-B relationship, culturally similarity facilitates information exchange.

To summarize, Similarity-Attraction Theory (Byrne, 1971) offers a parsimonious framework, which explains the reasons and mechanisms on people's attachment to others and how people are affected in their social worlds. Moreover, the theory asserts that similar attitudes, personalities, physical attributes among people in the same environment influence their attitudes and behaviors. In the organizational environment, people generally compare their attributes among their group members and assess if they are similar or dissimilar (Tsui and O'Reilly, 1989) based on their relational demographic factors. Similar people develop positive attitudes towards each other and behave positively; on the other hand, dissimilar individuals have a tendency to evaluate each other less favorably (Tsui et al., 2002). Thus, we argue that the more similarity (in terms of lifestyle, interests, preferences, values, etc.) there is between buyers and sellers the more sellers' trust in buyers will be. Therefore, we offer the following hypothesis:

$\mathbf{H}_{1}$ : Similarity is positively related to sellers' trust in buyers.

\subsection{Buyer Specific Factors}

The influence of buyer-specific factors on sellers' trust in buyers may be explained based on competence-based trust literature. Competence-based trust is confidence in the counterpart's experience, skills, and consistency, which are required to complete a specified task (Lui \& Ngo, 2004). In other words, trust in the counterpart is influenced by technical capability, performance history, 
and ability based on prior experience (Lee, 2004). For that reason, the counterpart is trusted when there is satisfactory evidence about the counterpart's competence. The competence-based trust is a result of the feeling like "He/she knows what he/she is talking about and it makes sense" (Parayitam, 2010). In accordance with the competence-based trust literature, we investigate the influence of buyer's two core competencies to the seller's trust in the buyer: Task orientation and expertise.

\section{Task Orientation}

Task-oriented individuals focus on the completion of a particular task as a measure of success. In a B2B sales situation, task orientation refers to both buyers and sellers focus on getting the sales job done (Keillor, Parker, and Pettijohn, 2000). Venkatesh, Kohli, and Zaltman (1995) defined task orientation (from a seller's perspective in a business setting) as an influential strategy and mentioned that task-oriented strategies, information exchange, and recommendations have a more visible, stronger positive influence to sales processes than non-task-oriented strategies. Previous research indicates that task-oriented (conscientious) salespeople drive higher objective sales performance (Yang et al, 2011). Gesteland (2002) mentioned that task-oriented people tend to close the deals as quickly as possible even occasionally be too pushy and aggressive. This is because the task-oriented buyers are highly result-focused in sales negotiations and try to complete the buying task as effective as possible (McFarland et al. 2006), which may emerge a higher trust in the buyer at the seller's side. Hence, we anticipate that sellers' perceptions of higher task-orientated buyers may generate a stronger trust in buyers. This leads us to the following hypothesis:

$\mathbf{H}_{2 \mathrm{a}}$ : When sellers perceive buyers to be more task-oriented, sellers' trust in buyers increases.

\section{Expertise}

In addition to buyers' task orientation, another important personal factor that may enable the sellers' trust in buyers is the buyers' expertise. Expertise is defined as the knowledge or skill in a particular field. In B2B marketing literature, quite a large number of studies have shown that sellers' expertise increases buyers' trust in sellers or if a buyer's perception of the seller's expertise is high the buyer would be more willing to trust that seller (i.e. Johnson and Grayson, 2005; Lai, Chou, and Cheung, 2013; Bataineh et al., 2015; Newell et al., 2016). Mansour, et al. (2016) also showed that the lack of expertise has a negative impact on trust. Moreover, Crosby et al (1990) found out that expertise can influence both short and long-term sales efficiency because expertise strengthens the positive perception of applicable features associated with the goods or service.

As argued earlier, trust is a two-sided relational element. Thus, this study argues that sellers' perceptions of higher levels of buyers' expertise may also have a positive impact on sellers' trust in buyers. Consequently, we suggest the following hypothesis:

$\mathbf{H}_{2 b}$ : When sellers perceive higher levels of buyers' expertise, sellers' trust in buyers increases.

\subsection{Sale Process Efficiency}

The principal aim of any buyer-seller relationship is to increase sales performance and sales performance has been quantified by academia with different measures including higher profit margin, higher total sales, exceeding sales targets, new product sales, long term customer satisfaction, customer retention and new account acquisition (Webber et al., 2018). Arndt and Harkins (2013) defined sales performance as "the timely completion of the activity at a quality which is sufficient for the needs of the buyer and the seller at the lowest reasonable cost" (Arndt and Harkins, 2013, p.434) indicating that sale process is a time-sensitive activity. Stoddard, Clopton, and Avila (2007) also argued that "the sales process efficiency construct includes task outcomes that streamline the sales process (e.g., better time and territory management, enhanced productivity, spending more time with customers, handling more accounts, lower cost of leads, and lower cost of sales)" (Stoddard, Clopton, and Avila, 2007, p.42). Thus, an important indicator of sales performance is the sale process efficiency since the quicker a sales activity is accomplished, the faster business transaction can be performed. Sale process efficiency is the capability to successfully close and complete sales calls in a shorter-term (Stoddard, Clopton, and Avila 2006) or in other words, it is the time-bound component of the sales performance. Based on Weitz' (1981) Contingency Framework, and Weitz, Sujan and Sujan's (1986) study about improving selling efficiency, this study suggests that the sale process and its nature (i.e. the duration of the sales job) are important indicators of the sales performance. We believe that sale process efficiency may be more robust in measuring sales performance than behavioral measures, especially in a B2B setting. 
The sale process includes certain events, such as customer communications including the initial sale call, company presentations, and contract negotiations, requiring information exchange during the process (Churchill et al., 2000). Previous research suggests that obtaining a trustful relationship between a buyer and seller creates a competitive advantage by increasing the sale process efficiency (Dyer and Chu, 2011), as increased trust generates increased information exchange, mutual disclosure and cooperative intentions of the salesperson (Boles, Johnson, and Barksdale, 2000). From this perspective, in order to be able to increase the sale process efficiency, both buyers and sellers would be willing to increase interpersonal and inter-organizational cooperation where trust is a crucial antecedent (Fan et al., 2012).

The relationship between trust and sale efficiency has been studied widely in the literature. For example, Crosby et al. (1990); Boles, Johnston, and Barksdale (2000); Wagner, Klein, and Keith (2003); and Johnson and Grayson (2005) examined the buyerseller relationships' influence on selling process efficiency and shown that trust is critical in maintaining higher sale process efficiency. Pullins, Reid, and Plank (2004) and Johnson and Grayson (2005) also provide evidence that trust positively influences sales performance. On the seller side of the relationship, when sellers perceive the buyer trustworthy, sales performance is increased (Chakrabarty et at, 2013). Similarly, we expect that when sellers have more trust in buyers, the sale process efficiency will be higher as well and thus we hypothesize:

$\mathbf{H}_{3}$ : Sellers' trust in buyers is positively related to sale process efficiency.

\subsection{Purchase Importance}

In his 1973 model of B2B buyer behavior, Sheth states that purchase importance is a product-specific factor, and it varies based on various factors. Purchase importance is categorized as one of the major situational factors that influences the selling process (Cannon and Perreault, 1999; Homburg, Müller, and Klarmann, 2011), which is defined as buyer's "perceptions of the strategic significance of a particular purchase to the organization's objectives" (Hutt and Speh, 2001, p. 93). As indicated by Anderson and Jap (2005) the as perceived risk increases purchase importance also increases since the termination costs for both buyer and seller grow for high purchase importance situations and thus such "mutual hostages" require higher trust (Anderson and Jap, 2005). Therefore, in cases of higher purchase importance trust may have a stronger influence on sale process efficiency and we hypothesize:

$\mathbf{H}_{4}$ : When perceived purchase importance is high, the positive influence of the seller's trust in the buyer on sale process efficiency will increase.

Figure 1: A Model of the Trust between B2B Buyers and Sellers

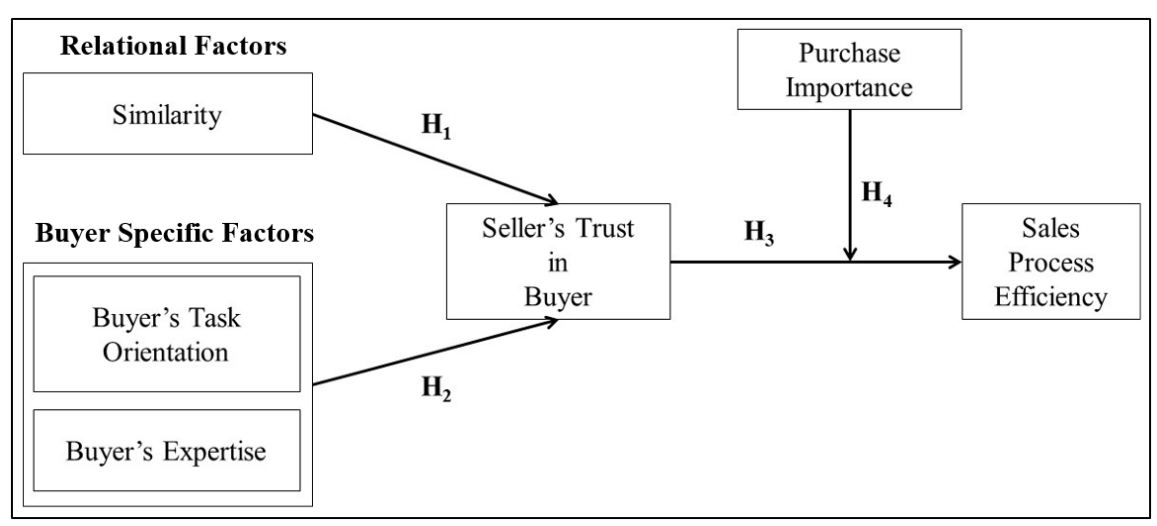

Previous research concludes that expertise helps overcome the tough situations and the natural outcome is the reduced risk due to increased trust between buyers and sellers. For instance, Crosby et al. (1990) showed that the seller's expertise reveals his/her relevant capabilities associated with the goods or services, which can generate trust between buyers and sellers. Even today at the internet age, with much easier information access at any level, expertise still shows a positive and significant effect on trust (Lai, Chou, and Cheung, 2013; Bataineh et al., 2015). Therefore, the seller's age, industry experience, and tenure in the company are added as a control variable. 


\section{DATA AND METHODOLOGY}

Different levels of involvement in decision-making and varying importance given to various criteria by each role in a B2B setting create confounding results when gathering reliable data from the buyer side of the relationship. In this study, buying decisionmakers' eccentricities and seller's trust in the buyer are examined by surveying salespeople for two reasons: (1) The nonpracticality of finding-out the real buying decision-maker in the B2B environment (Garrido-Samaniego and Gutierrez-Cillan, 2004) during a survey process and (2) the fact that the success of any salespeople lies in determining the real buying decision-maker during the B2B sales processes. Thus, using salespeople as the unit of analysis to measure the study variables is the best way to acquire information about the real decision maker in a particular sale. Therefore, a quantitative approach that takes salespeople as the unit of analysis is adopted.

\subsection{Data Collection}

A convenience sample of B2B salespeople working in a metropolitan area in East Europe is reached via an online data collection process. Using a large online membership database, 3000 survey invitations were emailed to randomly selected sales professionals. The survey link was accessible for three weeks and then a reminder email was sent one week after the initial request. The respondents were asked to think about their most recent (finalized) sale and consider the real buying decision-maker while answering the personal perceptions of the buyer. A total of 547 surveys were collected with a response rate of $18.23 \%$, however, only 235 of them were usable after eliminating the sales professionals working in final consumer markets.

181 (77\%) of the respondents were male while 54 (23\%) were female B2B sales professionals, from 6 different industries. The age range was between 22 and 62 with an average of 35.29 years. $25 \%$ of the respondents were below 30 years old, and $25 \%$ of the respondents were above 40 years old. The average industry experience of the sellers was 10.84 years, varying from 1 to 40 years. $25 \%$ of the respondents had less than 5 years and $25 \%$ of the respondents have more than 15 years of experience. The company tenure of the respondents varied from 1 to 39 years, with an average of 6.78 years. Demographics of the sample are presented in Table1.

\section{Table 1: Sample Demographics}

\begin{tabular}{|l|c|c|c|l|c|l|c|}
\hline Variable & Min & Max & Mean & Industry & Percentage & Industry & Percentage \\
\hline Seller's Age & 22 & 62 & 35.29 & Communications & $17 \%$ & Services & $33 \%$ \\
\hline Industry Experience & 1 & 40 & 10.84 & Energy & $4 \%$ & Production & $27 \%$ \\
\hline Tenure in the Company & 1 & 39 & 6.78 & Food and Drug & $13 \%$ & Construction & $6 \%$ \\
\hline
\end{tabular}

\subsection{Measures}

Almost all the measures of this study are derived from the existing literature. The questionnaire contained measures assessing the individual characteristics and demographics of the seller, as well as the seller's perception of the buyer's individual characteristics such as expertise, task orientation, and similarity. Both buyer's expertise (adopted from Johnson and Grayson 2005) and task orientation (adopted from Homburg, Müller and Klarmann 2011) were measured using three items. The similarity measure contained 10 items and is adapted from Karaosmanoglu, Elmadag Bas, and Zhang (2011). Trust is measured with three items derived from Doney and Cannon (1997) and adopted in accordance with the context of this study. We measured the purchase importance with 5-items derived from Cannon and Perreault (1999). All the constructs were measured using five-point Likert-type scale with the exception of sale process efficiency, for which each respondent was asked to provide the actual duration of the sale process and the industry average for similar situations. In other words, sale process efficiency is a measure of how timely this specific sale process was completed with respect to a similar situation and operationalized as the ratio of the total duration for the actual decision-making process and the sectoral average of the similar decision-making processes. Finally, control variables, seller's age, industry experience, and tenure in the company are measured by the number of years.

\section{ANALYSIS AND RESULTS}

Regression analysis was performed to check the effects of the control variables (age, industry experience and tenure in the company) on the overall model. The control variables were first included in the regression on both seller's trust in the buyer and sales process efficiency. Only tenure in the company had a significant effect on seller's trust in the buyer and when expertise, similarity and task orientation was added this effect disappeared. The results of the regression analysis are shown in Table 2. 
Secondly, we looked at the variance inflation factor (VIF), and the largest VIF has a value of 2.364. This result ruled out concerns related to multicollinearity in our data (Hair et al., 1998). Therefore, it was concluded that the data set would not cause systematic sample errors, and the data were pooled for subsequent analyses.

Table 2: Regression Analysis Results

\begin{tabular}{lll}
\hline & Sellers Trust in the Buyer & Sale Process Efficiency \\
\hline Step 1: & & \\
\hline Control variables & $-.092(-.876)$ & $-.055(-.521)$ \\
\hline Age & $-.079(-.638)$ & $-.051(-.402)$ \\
Industry Experience & $.0231^{* *}(2.440)$ & $.082(.856)$ \\
Tenure in the Company & & \\
\hline Step 2: & & $-.048(-.455)$ \\
\hline Control variables & $-.045(-.532)$ & $-.036(-.285)$ \\
$\quad$ Age & $-.058(-.577)$ & $.058(.602)$ \\
$\quad$ Industry Experience & $.113(1.472)$ & $-.022(-.221)$ \\
$\quad$ Tenure in the Company & $.288^{* *(3.642)}$ & $.173^{*}(1.719)$ \\
\hline Independent variables & $.298^{* * *}(3.711)$ & $.020(.294)$ \\
\hline$\quad$ Expertise & $.147^{* * *}(2.675)$ & \\
$\quad$ Sask Orientation & & \\
\hline
\end{tabular}

Note: Standardized coefficients are reported along with t values. ${ }^{*} p<.010,{ }^{* *} p<.005$, and ${ }^{* * *} p<.001$

To test the hypothesized relationships among the study constructs simultaneously based on a covariance-based procedure modeling of latent variables directly, we used structural equation modeling (SEM) using AMOS software version 24.0.0.

\subsection{Measurement Model and Structural Model Fit}

First, means and standard deviations, as well as the reliabilities of constructs, were examined. Cronbach's alpha values ( $\alpha$ ) were well above the suggested benchmark 0.7 (Nunnally, 1978) in all instances. Secondly, a confirmatory factor analysis (CFA) was carried out to establish convergent validity. Table 3 shows the means, standard deviations, loadings, and reliability estimates (composite reliability (CR) and average variance extracted (AVE)) for all study constructs. All CR values were above 0.80 and all AVEs were above 0.50 , indicating satisfactory levels of reliability. Moreover, all t values were higher than 6 , all factor loadings were greater than 0.5 , and all loadings were at least five times greater than its standard error indicating convergent validity (Gerbing and Anderson, 1992). Overall, scales are stable, produce consistent results and measure their intended constructs. Finally, we tested for non-response bias (Armstrong and Overton, 1977) and were not able to find any bias between early and late respondents.

Table 3: Dimensionality, Reliability and Correlations

\begin{tabular}{|c|c|c|c|c|c|c|c|c|c|c|}
\hline \multirow{2}{*}{ \# } & \multirow{2}{*}{ Construct } & \multirow{2}{*}{ Mean } & \multirow{2}{*}{ SD } & \multirow{2}{*}{$\alpha$} & \multirow{2}{*}{ CR } & \multirow{2}{*}{ AVE } & \multicolumn{4}{|c|}{ Correlations* } \\
\hline & & & & & & & 1 & 2 & 3 & 4 \\
\hline 1 & Expertise & 3.912 & .902 & .899 & .912 & .770 & 1 & .743 & .223 & .554 \\
\hline 2 & Task Orientation & 3.898 & .955 & .916 & .911 & .784 & & 1 & .321 & .568 \\
\hline 3 & Similarity & 2.787 & .900 & .898 & .848 & .503 & & & 1 & .308 \\
\hline 4 & Trust & 3.672 & 1.059 & .849 & .803 & .689 & & & & 1 \\
\hline
\end{tabular}

Note: $\alpha$ = Cronbach's alpha; CR = Composite Reliability; AVE = Average Variance Extracted; * All correlations are significant at the 0.01 (2-tailed).

Based on suggestions by Gerbing and Anderson (1992), the measurement model was evaluated and standardized $\chi^{2}$ value, comparative-fit index (CFI), standardized root mean square residual (SRMR) and root-mean-square-error-of-approximation (RMSEA) are reported. Measurement Model included all items for buyer's expertise, buyer's task orientation, similarity, seller's trust in the buyer and sale process efficiency. The measurement model achieved adequate fit $\left(\chi^{2}=313.758, d f=155, \chi^{2} / d f=, 2.024\right.$, $\mathrm{CFI}=0.95, \mathrm{SRMR}=0.0644, \mathrm{RMSEA}=0.066$ ). 


\subsection{Hypothesis Testing}

The results of analyses, before the inclusion of the moderation effects, indicate that all the studied personal factors and perceptions have positive and statistically significant (all $p<.05)$ influence on trust. Similarity $(\beta=.195, t=3.249)$ indicated a positive impact on trust; however, buyer-specific factors (buyer's task orientation $(\beta=.474, t=4.821)$ and buyer's expertise $(\beta=$ $.162, t=1.725)$ ) showed stronger positive influence on trust, which also has a positive influence on sale process efficiency $(\beta=$ $.136, t=2.009)$. These results are consistent with study expectations, so $\mathrm{H} 1, \mathrm{H} 2 \mathrm{a}, \mathrm{H} 2 \mathrm{~b}$, and $\mathrm{H} 3$ are supported. The result of our research model, comprising of antecedents and consequences of seller's trust in the buyer, is summarized and direct, indirect as well as total effects are reported in Table 4.

Figure 2: The Direct Effects ( $\left.\beta_{\text {direct }}\right)$ and $t$-values of the Proposed Relationships

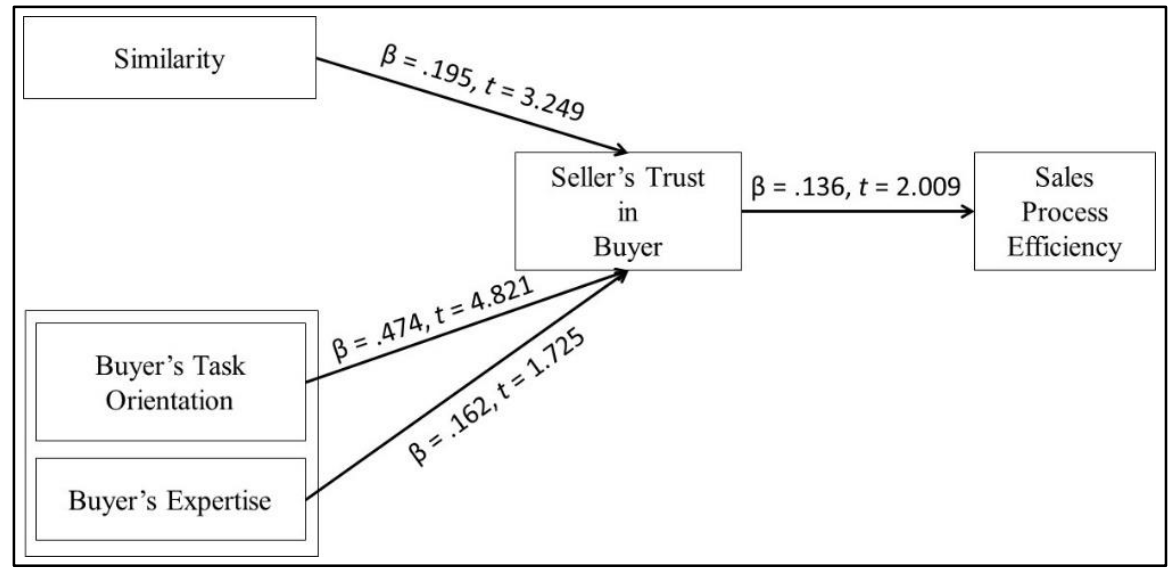

Table 4: Results of Hypothesis Tests for the Model

\begin{tabular}{|c|c|c|c|c|c|c|c|c|}
\hline \multirow{3}{*}{$\begin{array}{l}\# \\
\mathrm{H}_{1} \\
\end{array}$} & \multirow{2}{*}{\multicolumn{3}{|c|}{ Hypothesis }} & \multirow{3}{*}{$\begin{array}{l}\boldsymbol{\beta}_{\text {direct }} \\
0.195\end{array}$} & \multirow{3}{*}{$\begin{array}{c}\boldsymbol{t} \\
3.249 \\
\end{array}$} & \multirow{3}{*}{$\begin{array}{c}\mathbf{P} \\
<0.01 \\
\end{array}$} & $\beta_{\text {indirect }}$ & $\beta_{\text {total }}$ \\
\hline & & & & & & & \multicolumn{2}{|c|}{ on SP Efficiency } \\
\hline & Similarity & & Trust & & & & .027 & .027 \\
\hline $\mathrm{H}_{2 \mathrm{a}}$ & Task Orientation & $\rightarrow$ & Trust & 0.474 & 4.821 & $<0.01$ & .065 & .065 \\
\hline $\mathrm{H}_{2 b}$ & Expertise & & Trust & 0.162 & 1.725 & $<0.05$ & .022 & .022 \\
\hline $\mathrm{H}_{3}$ & Trust & & SP Efficiency & 0.136 & 2.009 & $<0.05$ & .000 & .136 \\
\hline
\end{tabular}

Note: Standardized regression weights for direct effects ( $\beta_{\text {direct }}$ ) and $t$-values are given. Standardized regression weights for indirect effects ( $\left.\beta_{\text {indirect }}\right)$ to $S P$ efficiency and total effects $\left(\beta_{\text {total }}\right)$ are given $(n=235$, chi-square $=345.612, d f=160$, RMSEA $=0.070, C F I=0.94, S R M R=0.1255)$.

\subsection{Multi-group Invariance Tests and Moderation Effects}

The purpose of the moderation analysis is to examine and express the situational effects that may influence the strength of the structural relationships. In order to test the moderating influence of purchase importance on the strength of the relationship between sellers' trust in buyers and sale process efficiency $\left(\mathrm{H}_{4}\right)$, a multiple-group analysis was performed using AMOS.

Respondents were split into two groups using a mean split of the perceived purchase importance level of the buyer: (1) Low purchase importance and (2) High purchase importance. First, in testing the measurement invariance, a multi-group model was specified in which all factor loadings and all factor variances were constrained equal across the two groups. In testing whether the relationship between trust and sale process efficiency differ across low and high purchase importance situations $(H 4)$, we first compared a fully constrained model in which the path is constrained $\left(\chi^{2}=545.1, d f=321\right)$ equal across subgroups (i.e. low and high purchase importance) to an unconstrained model $\left(\chi^{2}=541.3, d f=320\right)$ in which the path 
is allowed to vary freely. The results of the $\chi 2$ difference test showed that the groups vary at the model level $\left(\Delta \chi 2_{(1)}=3,85\right.$, $p<0.05)$ indicating that differences in the path relationships between low and high groups exist. Thus, $H 4$ is supported.

Moreover, to test the relationship at the path level the critical difference ratios regarding the path coefficients were calculated. The coefficient of high purchase importance group (.458) is higher than the low purchase importance group's coefficient (.112) on the sellers' trust in the buyers and sales process efficiency relationship, and the critical difference ratio was significant $(t=$ $1.651, p<.05)$. Finally, sellers' trust in buyers and sales process efficiency relationship is significant at high purchase importance group $(\beta=.239, t=2.446, \mathrm{p}<.05)$; but not significant at low purchase importance group $(\beta=.101, t=1.068, \mathrm{p}>.05)$. These findings also provide further support for $\mathrm{H}_{4}$ that when purchase importance is perceived high, the positive influence of sellers' trust in buyers on sale process efficiency will increase.

\section{CONCLUSION}

Sale process efficiency is critical for both the selling and the buying organizations in order to reduce the resources (human, energy, time, etc.) spent on each sale process (or buying process for the buying company). Based on the theoretical premise that similarity between buyer and seller (Tsui and O'Reilly, 1989; Doney and Cannon, 1997), buyer's task orientation (Venkatesh, Kohli and Zaltman, 1995) and buyer's expertise (Crosby et al., 1990; Doney and Cannon, 1997) may have a bearing on trust, this study quantitatively tests a model of seller's trust in the buyer and its influence on sale process efficiency.

The antecedents of trust including similarity (Doney and Cannon, 1997; Lichtenthal and Tellefsen, 2001; Child and Möllering, 2003; Weck and Ivanova, 2013), expertise (Doney and Cannon, 1997; Johnson and Grayson, 2005), and task orientation (Gesteland, 2002; McFarland et al. 2006); as well as the sale process efficiency as a consequence of trust (Boles, Johnston, and Barksdale, 2000; Wagner, Klein, and Keith, 2003; Pullins, Reid and Plank, 2004) have been addressed in several studies in the existing marketing literature; however the studies including these variables have primarily focused on the buyer's trust in the seller, the seller's expertise and the buyer's perceptions of seller similarity. On the other hand, the buyer-seller relationship is a two-way street, and thus this study fills in the gap in the literature about the seller's perception of buyer's similarity, expertise, and task orientation, and their outcomes in terms of seller's trust in the buyer and sale process efficiency.

\subsection{Theoretical implications}

The results of this study indicate that when sellers perceive buyers to be more similar, task-oriented experts, the seller's trust in the buyer and sale process efficiency increases. Thus, this study confirms the discussed and hypothesized positive influences of personal factors on the sale process efficiency in B2B settings. These results suggest that the buyer-seller similarity, task orientation, and expertise, may be integrated into the current $\mathrm{B} 2 \mathrm{~B}$ buyer behavior model, which will improve our understanding of B2B salesperson performance.

The outcome of this study also recommends that "similarity" can be a new dimension for "adaptive selling". The general definition of "adaptive selling" is "the altering of sales behaviors during or across customer interactions based upon perceived information about the nature of the selling situation" (Weitz, Sujan, and Sujan 1986). From this perspective, the fast assessment capability of the seller about the buyer attitudes and beliefs may help to emphasize points of similarity during sales calls as well as to avoid the discussions related to the points of dissimilarity; an evaluation which is aligned with the "adaptive selling behavior".

Another important finding of our study is the moderating effect of the purchase importance on the relationship between seller's trust in the buyer and sale process efficiency. When we split the sample into two groups based on perceived purchase importance levels, we have reached interesting results. The hypothesized positive effect of the perceived purchase importance on the strength of the relationship between the seller's trust in the buyer and the sale process efficiency $\left(\mathrm{H}_{4}\right)$ is supported. Moreover, when purchase importance is high there is a significant positive relationship between seller's trust in the buyer and sale process efficiency, however, this relationship becomes statistically insignificant for the low purchase important group. These findings might be related to the sellers' increased risk perception of the buyer for more important purchase situations compared to less important purchase situations (Jackson, 1985). It is reasonable to assume that when a salesperson trusts the buyer, the salesperson may share more information with the buyer, and therefore reduces risk perception of the buyer, which helps to increase the trust in the seller due to reduced uncertainty of consequences (Doney and Cannon, 1997). This risk reduction mechanism helps to expedite the decision period for the buyer, increasing the sale process efficiency. This result might be practically expected, however to the best of our knowledge this study is the first attempt to show this moderation effect in an empirical setting which can be considered as a contribution to the marketing theory. 


\subsection{Managerial Implications}

This study proves that the similarity between seller and buyer has a significant positive influence on the trust, which has a significant positive influence on the sale process efficiency in business-to-business contexts. From that perspective, if the sales team managers want to increase the sale process efficiency, they need to assign similar sellers to their buyer counterparts.

This finding is grounded by the previous researches as the findings indicate that similarity supports the development of trust as similar people tend to evaluate each other more favorably compared to the dissimilar ones (Tsui et al., 2002). The results of this study may help the sales team managers understand the influence of similarity between buyer and seller in a sale situation. Such understanding will assist those in assigning the customers to their team members; and develop methods and techniques to enable salespeople personally assess the degree of similarity with a specific buyer, hence modify their sales behaviors.

Even though matching sellers and buyers based on similarity might sound logical and effective, but it may also pose important managerial problems in an age where customers in some industries may be mostly male or white and enlightened sellers will want to assign women or non-white sales professionals to call on dissimilar prospects. For that reason, team managers also recognize the complex societal and legal factors while assigning the team members to his/her counterparts. Although similarity has a dark side due to possible discriminatory consequences, this study provides an understanding of how the model of similarity can be integrated into salesperson recruiting processes and validates that it is vital for hiring managers to evaluate candidates while considering their awareness and the capability to rapidly examine buyer attitudes and beliefs to determine the similar characteristics.

Another important managerial implication is for procurement organizations. Results indicate that sales (procurement) process efficiency is facilitated by sellers' trust in the buyer when purchase importance is high. If the procurement team managers want to increase their process efficiency for high importance tasks, they may need to assign higher expertise and/or higher taskoriented buyers to this particular procurement activity.

Finally, the results of the moderation analysis reveal that the sales team manager needs to motivate their sellers to trust their buyers more at higher purchase importance situations in order to increase the sale process efficiency in B2B settings. The application of this implication might be a more challenging for the sales team managers since the selling situation is not the core competency of a sales team manager, but a sales team member.

\subsection{Limitations and Suggestions for Future Research}

We have confidence in our theoretical model about the trust between buyer and seller in the business setting and its contributions to an important, and growing topics for practitioners and researchers in B2B marketing. However, the findings based on our theoretical model have certain limitations that require future research to develop the field further.

This study breaks new ground by studying perceptions exclusively from the seller's point of view. This one-way perspective is worth investigating and contributes to our understanding of buyer-seller relations, however, our research has been conducted only from one perspective and one level (salesperson - buying decision-maker) of a dyadic, multi-level phenomenon. Yet this dyadic phenomenon involves not just person-to-person but also firm-to-firm or person-to-firm or firm-to-person interactions. Thus, the other levels of this dyadic phenomenon, as well as perspectives are worth investigating as well. As the results of this study are derived exclusively from the seller's perspective, it might be interesting to replicate a similar study both buyers and sellers' perspectives concurrently, both from individual and firm levels.

The other concern is about the sale process efficiency as a dependent variable. Sale process efficiency is a time-bound measure of sales performance, which can be defined as the execution of salespersons' correct behaviors and the results of those behaviors to the achievement of organizational goals in a specified timeframe (Hyman \& Sager, 1999). However, buyer-seller relationship building is a long-term process and that might be determined not only by how quickly the sale process is completed, but also by the purchase history, size of the order, new account acquisition, or long-term customer satisfaction. Therefore, the replication of this study with not only sale process efficiency but also other aspects of sales performance might be suggested.

The final concern about this research is the generalizability of the results. The survey was conducted on the seller perceptions about buyer similarity or expertise in several industries, however, the ideal situation is conducting the research by one specific industry to eliminate the differences in industry dynamics. Overall, the findings of our study may have interesting implications for marketing theory. Our study also suggests significant opportunities for future researches. 


\section{REFERENCES}

Akrout, W. \& Akrout, H. (2011). Trust in B-to-B: Toward a Dynamic and Integrative Approach, Recherche et Applications Marketing (English Edition), Vol. 26, pp. 1-21.

Anderson, E., \&Jap, S.D. (2005). The dark side of close relationships, Sloan Management Review, Vol.46, pp. 74-83.

Anderson, E. \&Narus, J. (1990). A model of distributor firm and manufacturer firm working partnerships, Journal of Marketing, Vol. 54 No. 1, pp. 42-58.

Armstrong, J.S. \&Overton, T.S. (1977). Estimating nonresponse bias in mail surveys, Journal of Marketing Research, Vol. 14 No. 3, pp. $396-402$.

Arndt, A.D., \& Harkins, J. (2013). A framework for configuring sales support structure, Journal of Business \& Industrial Marketing, Vol. 28, Issue: 5, pp.432-443.

Baron, J.N. \&Pfeffer, J. (1994). The social psychology of organizations and inequality, Social Psychology Quarterly, Vol. 57, pp. 190-209.

Bataineh, A.Q., Al-Abdallah, G.M., Salhab, H.A. \&Shoter, A.M. (2015). The Effect of Relationship Marketing on Customer Retention in the Jordanian's Pharmaceutical Sector, International Journal of Business and Management, Vol. 10, No. 3.

Bateman, C., \&Valentine, S. (2015). The impact of salesperson customer orientation on the evaluation of a salesperson's ethical treatment, trust in the salesperson, and intentions to purchase, Journal of Personal Selling \& Sales Management, Vol. 35, pp. 125-142.

Belonax J.J., Newell, S.J. \&Plank, R.E. (2007). The role of purchase importance on Buyer perceptions of the trust and expertise components of Supplier and Salesperson credibility in Business-to-Business Relationships, Journal of Personal Selling \& Sales Management, Vol. 37, pp. 247-258.

Blonska, A., Storey, C., Rozemeijer, F., Wetzels, M. \&Ruyter, K. (2013). Decomposing the effect of supplier development on relationship benefits: The role of relational capital, Industrial Marketing Management, Vol.42, pp. 1295-1306.

Boles, J.S., Johnson, J.T. \&Barksdale, H.C. (2000). How Salespeople Build Quality Relationships: A Replication and Extension, Journal of Business Research, 48, pp. 75-81.

Byrne, D. (1971). The Attraction Paradigm, New York: Academic Press.

Cannon, J.P., \& Perreault, W.D. (1999). Buyer-Seller Relationships in Business Markets, Journal of Marketing Research, Vol. 36, $439-460$.

Chakrabarty, S., Brown, G. \& Widing II, R. E. (2013). Distinguishing Between the Roles of Customer-Oriented Selling and Adaptive Selling in Managing Dysfunctional Conflict in Buyer-Seller Relationships, Journal of Personal Selling \& Sales Management, Vol. 33, pp. 245-260.

Child, J. \& Möllering, G. (2003). Contextual confidence and active trust development in the Chinese business environment, Organization Science, Vol. 14 No. 1, pp. 69-80.

Crosby, L.A., Evans, K.R. \& Cowles, D. (1990). Relationship Quality in Services Selling: An Interpersonal Influence Perspective, Journal of Marketing, Vol. 54, 3.

Dampérat, M. \& Jolibert, A. (2009). A dialectical model of buyer-seller relationships, Journal of Business \& Industrial Marketing, Vol. 24 Issue: $3 / 4$, pp. 207-217.

Dickie, J. (2004). Increasing sales effectiveness by blending CMM and CRM. In Defying the limits: The CRM project, Vol. 5, pp. 58-60. San Francisco: Montgomery Research.

Doney, P. \& Cannon, J. (1997). An examination of the nature of trust in buyer-seller relationships, Journal of Marketing, Vol. 61, pp. 35-51.

Dyer, J.H., \& Chu, W. (2011). The determinants of trust in supplier-automaker relationships in the US, Japan, and Korea, Journal of International Business Studies, Vol. 42, pp. 10-27.

Fan, Y.H., Woodbine, G. \& Scully, G. (2012). Guanxi and its influence on the judgments of Chinese auditors, Asia Pacific Business Review, Vol. 18, pp. 83-97.

Friend, S.B., Hamwi, G. A. \& Rutherford, B.N. (2011). Buyer-Seller Relationships Within a Multisource Context: Understanding Customer Defection and Available Alternatives, Journal of Personal Selling \& Sales Management, Vol. 31, pp. 383-395.

Gao, T., Sirgy, M.J. \& Bird, M.M. (2005). Reducing buyer decision-making uncertainty in organizational purchasing: can supplier trust, commitment, and dependence help?, Journal of Business Research, 58, pp. 397-405.

Garrido-Samaniego, M. J. \& Gutierrez-Cillan, J. (2004). Determinants of Influence and Participation in the Buying Center. An Analysis of Spanish Industrial Companies, The Journal of Business \& Industrial Marketing, 19, 4/5, pg. 320. 
Gerbing, D. W. \& Anderson, J. C. (1992). Monte carlo evaluations of goodness of fit indices for structural equation models, Sociological Methods and Research, pp. 132-160.

Gesteland, R. R. (2002). Cross-cultural business behavior Marketing, negotiating and managing across cultures (2nd ed.), Copenhagen: Handelshøjskolens Forlag, Copenhagen Business School Press.

Graca, S.S., Barry, J.M. \& Doney, P.M. (2015). Performance outcomes of behavioral attributes in buyer-supplier relationships, Journal of Business \& Industrial Marketing, Vol. 30 Issue: 7, pp.805-816.

Hair, J. F. Jr., Anderson, R. E., Tatham, R. L. \& Black, W. C. (1998). Multivariate Data Analysis (5th ed.). Prentice-Hall International, Upper Saddle River, NJ.

Hikkerovaa, L. (2011). The Effectiveness of Loyalty Programs: An Application in the Hospitality Industry, International Journal of Business, Vol. 16, Issue: 2, pp.150-164.

Hillier, T. J. (1975). Decision-making in the corporate industrial buying process, Industrial Marketing Management, 4(2-3), pp. 99-106.

Homburg, C., Müller, M. \& Klarmann, M. (2011). When does salespeople's customer orientation lead to customer loyalty? The differential effects of relational and functional customer orientation, Journal of the Academy of Marketing Science, 39, pp. $795-812$.

Hutt, M.D., \& Speh, T.W. (2001). Business Marketing Management, Thomson Learning, Mason, OH.

Hyman, M. R., \& Sager, J. K. (1999). Marginally performing salespeople: a definition. Journal of Personal Selling and Sales Management, 19(4), 67-74.

Jackson, B.B., (1985). Build customer-relationships that last, Harvard Business Review, Vol. 63, pp. 120-8.

Johnson, D. \& Grayson, K. (2005). Cognitive and affective trust in service relationships, Journal of Business Research, Issue 58, pp. 500-507.

Kalra, A., Agnihotri, R., Chaker, N. N., Singh, R. K. \& Das, B. K. (2017). Connect within to connect outside: effect of salespeople's political skill on relationship performance, Journal of Personal Selling \& Sales Management, Vol. 37, pp.332-348.

Karaosmanoglu, E., Elmadag Bas, A.B. \& Zhang, J. (2011). The role of other customer effect in corporate marketing, European Journal of Marketing, Vol. 45 No. 9/10, pp. 1416-1445.

Keillor, Bruce D., R. Stephen Parker, \& Charles E. Pettijohn (2000). Relationship-oriented characteristics and individual salesperson performance, Journal of Business \& Industrial Marketing, 15.1 pp. 7-22.

Lai, C.S., Pai, D.C., Yang, C.F. \& Lin, H.J. (2009). The effects of market orientation on relationship learning and relationship performance in industrial marketing: The dyadic perspectives, Industrial Marketing Management, Vol. 38, pp. 166-172.

Lai, M.C., Chou, F.S. \& Cheung, Y.J. (2013). Investigating Relational Selling Behaviors, Relationship Quality and Customer Loyalty in the Medical Device Industry in Taiwan, International Journal of Business and Information, Vol. 8 (1), pp.137-150.

Lee, H. J., (2004). The role of competence-based trust and organizational identification in continuous improvement. Journal of Managerial Psychology, Vol. 19, pp. 623-639.

Lichtenthal, D.J. \& Tellefsen, T. (2001). Toward a theory of business buyer-seller similarity, Journal of Personal Selling \& Sales Management, Vol. 21 No. 1, pp. 1-14.

Lui, S. S., \& Ngo, H. Y. (2004). The role of trust and contractual safeguards on cooperation in non-equity alliances. Journal of Management, Vol. 30, pp. 471-485.

Mansour,W., Hajlaoui, L.L., Abdulkarim, F. \& Nassief, M. (2016). Trust Crisis in Islamic Banking: Empirical Evidence Using Structural Equations Modeling, International Journal of Business, Vol. 21, pp.157-177.

Massey, G.R., Wang, P.Z. \& Kyngdon, A.S. (2019). Conceptualizing and modeling interpersonal trust in exchange relationships: The effects of incomplete model specification, Industrial Marketing Management, Vol. 76, pp. 60-71

McFarland, R. G., Challagalla, G. N., \& Shervani, T. A. (2006). Influence tactics for effective adaptive selling, Journal of Marketing, 70, $103-117$.

Moorman, C., Zaltman, G. \& Deshpande', R. (1992). Relationships Between Providers and Users of Market Research: The Dynamics of Trust Within and Between Organizations, Journal of Marketing Research, 29, pp. 314-29.

Morgan, R. \& Hunt, S. (1994). The commitment - trust theory of relationship marketing, Journal of Marketing, Vol. 58, pp. 20-38. 
Newell, S. J., Wu, B., Leingpibul, D. \& Jiang, Y. (2016). The importance of corporate and salesperson expertise and trust in building loyal businessto-business relationships in China, Journal of Personal Selling \& Sales Management, Vol. 36, pp. 160-173.

Nunnally, J.C. (1978). Psychometric Theory, McGraw-Hill, New York, NY.

Nyaga, G.N., Whipple, J.M. \& Lynch, D.F. (2010). Examining supply chain relationships: Do buyer and supplier perspectives on collaborative relationships differ?, Journal of Operations Management, Vol. 28, pp. 101-114.

Parasuraman, A., Zeithaml, V. A., \& Berry, L. L. (1985). A conceptual model of service quality and its implications for future research, Journal of Marketing, 49, 41- 50.

Parayitam, S. (2010). The effect of competence-based trust between physicians and administrative executives in healthcare on decision outcomes. Management Research Review, Vol. 33, pp. 174-191.

Plouffe, C.R. (2018). Is it navigation, networking, coordination ... or what? A multidisciplinary review of influences on the intraorganizational dimension of the sales role and performance, Journal of Personal Selling \& Sales Management, Vol. 38, pp.241-264.

Pullins, E.B., Reid, D. A. \& Plank, R.E. (2004). Gender Issues in Buyer-Seller Relationships: Does Gender Matter in Purchasing?, Journal of Supply Chain Management, 40, 3, pg. 40-48.

Rodriguez, M., \& Honeycutt, E. (2011). Customer Relationship Management (CRM)'s Impact on B to B Sales Professionals' Collaboration and Sales Performance, Journal of Business-to-Business Marketing, Vol.18, 4, pp. 335-356.

Rungsithong, R., Meyer, K.E., \& Roath, A.S. (2017). Relational capabilities in Thai buyer-supplier relationships, Journal of Business \& Industrial Marketing, 32, 1228-1244.

Sheth, J.N. (1973). A Model of Industrial Buyer Behavior, Journal of Marketing, Vol. 37, No. 4, pp. 50-56.

Smith, J.B. (1998). Buyer-seller relationships: similarity, relationship management, and quality, Psychology and Marketing, Vol. 15 , pp. 3-21.

Stoddard, J.E., Clopton, S.W. \& Avila, R.A. (2006). An analysis of the effects of sales force automation on salesperson perceptions of performance, Journal of Selling and Major Account Management, Vol. 6, pp. 38-56.

Stoddard, J.E., Clopton, S.W. \& Avila, R.A. (2007). Sales Managers' Perceptions of the Benefits of Sales Force Automation, Journal of Selling and Major Account Management, Vol. 7, pp. 37-50.

Swan, J.E. \& Nolan, J.J. (1985). Gaining Customer Trust: A Conceptual Guide for the Salesperson, Journal of Personal Selling \& Sales Management, Vol. 5, pp. 39-48.

Swan, J. E., Trawick I. F. Jr, Rink, D. R. \& Roberts, J.J. (1988). Measuring dimensions of purchaser trust of industrial salespeople. Journal of Personal Selling \& Sales Management, Vol 8, pp.1-10.

Tsui, A.S., \& O’Reilly, C.A. (1989). Beyond simple demographic effects: The importance of relational demography in superior-subordinate dyads, Academy of Management Journal, 32, 402-423.

Tsui, A.S., Porter, L.W. \& Egan, T.D. (2002). When both similarities and dissimilarities matter: Extending the concept of relational demography, Human Relations, 55, pp. 899-929.

Vázquez-Casielles, R., Iglesias,V. \& Varela-Neira, C. (2017). Manufacturer-distributor relationships: role of relationship-specific investment and dependence types, Journal of Business \& Industrial Marketing, Vol. 32 Issue: 8, 1245-1260.

Venkatesh, R., Kohli, A.J. \& Zaltman, G. (1995). Influence Strategies in Buying Centers, Journal of Marketing, Vol. 59, No. 4, pp. 71-82.

Wagner, J.A., Klein, N.M. \& Keith, J.E. (2003). Buyer-seller relationships and selling effectiveness: the moderating influence of buyer expertise and product competitive position, Journal of Business Research, 56, pp. $295-302$.

Webber, C. C., Sausen, J. O., Basso, K. \& Laimer, C. G. (2018). Remodelling the retail store for better sales performance, International Journal of Retail \& Distribution Management, Vol. 46, pp.1041-1055.

Webster, F.E. (1965). Modelling the Industrial Buying Process, Journal of Marketing Research, Vol.2 No.4, pp. $370-376$.

Webster, F.E. \& Wind, Y. (1972). A General Model for Understanding Organizational Buying Behavior, Journal of Marketing, Vol. 36, No. 2 (Apr., 1972), pp. 12-19.

Weck, M. \& Ivanova, M. (2013). The importance of cultural adaptation for the trust development within business relationships, Journal of Business \& Industrial Marketing, Vol. 28 Issue: 3, pp.210-220. 
Weitz, B., (1981). Effectiveness in Sales Interactions: A Contingency Framework. Journal of Marketing, Vol. 45, pp. 85-103.

Weitz, B., Sujan, H. \& Sujan, M. (1986). Knowledge, Motivation, and Adaptive Behavior: A Framework for Improving Selling Effectiveness. Journal of Marketing, Vol. 50, pp.174-191.

Yang, B., Kim, Y. \& McFarland, R. G. (2011). Individual Differences and Sales Performance: A Distal-Proximal Mediation Model of Self-Efficacy, Conscientiousness, and Extraversion, Journal of Personal Selling \& Sales Management, Vol. 31, pp.371-381. 